Open Access

\title{
Determinants of entrepreneurial capability (EC) environment in ASEAN-05 economies - a log-linear stochastic frontier analysis
}

\author{
Munshi Naser Ibne Afzal ${ }^{1,2,3^{*}}$, Shamim Siddiquii ${ }^{4}$ and Susmita Dutta ${ }^{5}$
}

\author{
*Correspondence: munshi.naser@ \\ gmail.com; munshi.naser@ums.edu. \\ my \\ ${ }^{1}$ Faculty of Business, Economics \& \\ Accountancy, University Malaysia \\ Sabah (UMS), Kota Kinabalu, \\ Malaysia \\ ${ }^{2}$ Department of Economics, \\ Shahjalal University of Science \& \\ Technology (SUST), Sylhet, \\ Bangladesh \\ Full list of author information is \\ available at the end of the article
}

\begin{abstract}
The primary driver of this study is to find out key indicators of Entrepreneurial Capability milieu and test these components empirically in the Association with South East Asian Nations-05 economies. The purpose of this study is twofold. Firstly, it attempts to understand the determinants of Entrepreneurial Capability which identifies and endeavor commercial opportunities in the Association of South East Asian Nations 05 economies, namely Indonesia, Malaysia, the Philippines, Singapore and Thailand. Secondly, using the theory and determinants of entrepreneurial capability in general, this study empirically tests the efficiency imperative coefficients of variables that have an impact on entrepreneurial perceived capabilities. This research applies recent consistent estimation of log linear transformation stochastic frontier model to find out time-variant changes of variables in the panel sample. Data and variables have collected from Global Entrepreneurship Monitor - 2016 and World Competitiveness Yearbook - 2016 during the years 2010-2016. The results suggest that Entrepreneurship as a Good Career Choice and Perceived Opportunities are two significant variables which can improve and have a positive influence on entrepreneurial capability while Fear of failure rate has a negative impact on the efficiency of entrepreneurial capability in the Association of South East Asian Nations-05 countries. Other important variables such as Intellectual Property Rights, University Education and Knowledge Transfer rate have a positive stimulus to the entrepreneurial capability environment in these economies. The findings of this study are important contributions to the entrepreneurship literature and help policymakers to rethink entrepreneurial capability settings of the Association of South East Asian Nations-05 countries to pursue an innovation-driven region in future.
\end{abstract}

Keywords: ASEAN-05, Entrepreneurial capability, Panel study, Stochastic frontier analysis (SFA), Fixed effect model, Entrepreneurial environment

JEL code: $\mathrm{O} 20,030,057$

\section{Background}

A great number of researchers focus on the linkage between the Entrepreneurial Perceived Capability (hereafter EC) study and innovation-driven development from the university-industry-government perspective (Miranda, Chamorro-Mera and Rubio 2017; Cantu-Ortiz, Galeano, Mora-Castro and Fangmeyer 2017; Tofighi, Teymourzadeh and

(C) The Author(s). 2018 Open Access This article is distributed under the terms of the Creative Commons Attribution 4.0 International License (http://creativecommons.org/licenses/by/4.0/), which permits unrestricted use, distribution, and reproduction in any medium, provided you give appropriate credit to the original author(s) and the source, provide a link to the Creative Commons license, and indicate if changes were made. 
Ghanizadeh 2017). Most of these cases have explored Entrepreneurial Intention (EI) rather than the factor affecting perceived capabilities of entrepreneurship (Siegel and Wright 2015). The EC implies that the potential entrepreneurs are using their skill and knowledge to identify, categorize and exploit entrepreneurial opportunities in university-industry-government set up for knowledge-based development (Nazaryeva 2015; Šebjan, Tominc and Boršič 2016; Nyström 2008). This is a crucial issue for both the EC and university-industry-government linkages literature (Afzal, Mansur and Sulong 2017; Antonioli, Nicolli, Ramaciotti and Rizzo 2016; Etzkowitz 2014).

Moreover, the EC study of a cross-country or regional block point of view remains an under-study area of research (Šebjan et al. 2016). An evident gap exists in research of EC that concentrate on regions and cross-country study. Some limited numbers of countries have been included in past research of this kind (D'este, Mahdi and Neely 2009). Thus, the present study contributes to narrowing this gap by focusing on the five countries in the ASEAN region. These countries are historically quite different in culture, size and income per capita while integrated into the pursuit of a common economic policy to become an innovation-driven region in the future (Scippacercola and D'Ambra 2014).

EC in university-industry-government set-up has changed dramatically from the inception of Bayh-Dole Act in the U.S. in 1980 (Nyström 2008). This act has given strong emphasis on university technology transfer, patenting and licensing based on overall entrepreneurship capabilities in the country. However, little attention was paid to the key attributes of EC skill and the start-up dimension (Hallam, Novick, Gilbert, Frankwick and Zanella 2017). Recently, many countries across the world, in particular, ASEAN-05 have emphasized EC environment into their economic development mission (Rashed, Deluyi and Daud 2015). Arafat and Saleem (2017) found that the major determinants of new business start-ups are gender, perceived opportunities, self-efficacy and risk perception in India. It is believed by many current entrepreneurship researchers that theoretical and empirical research on EC needs to improve the consistency and relevance of future studies on this topic (Bergmann, Mueller and Schrettle 2014).

The use of global entrepreneurship monitor data in this study has helped us to understand the relationship between EC and its determinants. Therefore, the main objective of this current research is firstly, investigating the number of factors emphasized in the literature as inducing the capacity of entrepreneurs to identify and exploit commercial opportunities. Secondly, empirically testing the identified factors using recent consistent estimation of fixed-effects, stochastic and linear transformation frontier models to find out significant variables in this framework (Chen, Schmidt and Wang 2014). The practical implication of this research is to help policy makers to understand of the ASEAN region to stimulate an EC environment by considering the important factors in individual countries and regions as a whole to strengthen university-industry-government linkage and creating employment opportunities for the new generation of entrepreneurs.

\section{Entrepreneurial capability (EC) working framework}

This study follows the entrepreneurship perceived capability-based framework. There are other frameworks such as the resource-based framework and the entrepreneurial 
intention framework (Giuri, Grimaldi and Villani 2014). Resources and capabilities-based frameworks are two different attributes of the inclosing capability of an entrepreneur (Schumpeter 1942). The resource-based opinion emphasizes on supply and entree to resources whilst the capability-based framework stresses on skill and agency (Audu, Otitolaiye and Ibitoye 2013). There are very few studies that are using a capability-based framework. Many researchers have suggested that it is the capability-based framework that spurs the innovation and global business start-up (Bergmann et al. 2014).

The entrepreneurial perceived capability-based framework emphasizes on the capabilities on supply of resources and seek opportunities to formulate start-up using entrepreneur skill and knowledge (Siegel and Wright 2015). The capability-based framework is divided into three capabilities which ease organizational spin-offs; e.g. opening new paths of action, balancing organization and commercial interests, and integrating new resources (Afzal, Mansur and Sulong 2017). Opening new paths of action is the first category in which entrepreneur seeks to explore new business ideas within the entrepreneurship eco-system. For example, patenting and licensing of a new discovery from a university may reveal a new path of action toward entrepreneurship. This is mostly depending on the status of the university education system, the knowledge transfer rate between university and industry and finally the strength of a country's Intellectual Property Rights (IPR) law (Woo, Jang and Kim 2015). The capability to balance organizational and commercial interests has to do with legitimizing both organizational and commercial activities. In this case, an incubation facility of entrepreneur strikes this balance and foster spin-offs. Finally, the capability to integrate new resources depends upon entrepreneur's personal networking and entrepreneurship opportunities in the country. Moreover, it is also suggested by researchers that, entrepreneurs will look for the opportunity if they believe entrepreneurship is a good career choice in the country. This thought will certainly push forward the entrepreneurial capabilities to capitalize on networks and resources globally (Light and Dana 2013). Thus, in this study, we have taken the aforementioned variables and entrepreneurship capability-based framework into account for empirical analyses.

\section{Brief literature review}

Various studies have been conducted on the aspects of entrepreneurship capabilities. These studies examined the territorial aspects (Wright 2007), compared the entrepreneurs in different geographical context (Klofsten and Jones-Evans 2000), or even assessed the factor based impacts on entrepreneurship models (Clarysse, Tartari and Salter 2011).

Tofighi et al. (2017) has studied the academic entrepreneurial situation in the dynamic approach in the context of Iran. They used a non - probability version of Cross Impact Analysis (CIA). Remarking some significant notion, the study concluded that the entrepreneurial ecosystem is a flourishing concept but there remained some structural obligations which they proposed should be improved to nurture the entrepreneurship environment.

Rashed et al. (2015) performed the Structural Equation Model (SEM) in two steps to develop a mathematical model of entrepreneurship. Their study was based on the 
transformational leadership behavior. They found that transformational leadership quality has an enormous influence on the entrepreneurial practice. The population of that study was all of the stuff from a public university in Iran. On the contrary, using structural equation model, Ahmed, Ali and Ramzan (2014) found that entrepreneurial orientation of individuals increased in the presence of the organizational factors and leader's entrepreneurial orientation among IT firms.

Hallam et al. (2017) conducted a multi-methodological study in the transformation project of the University of Texas. That study comprised the awareness survey. The study found the progressive entrepreneurial milieu is the prime to foster the commercialization of university-based technology. Moreover, social entrepreneurial intention can be explained by emotional intelligence and creativity (Tiwari and Tikoria 2017).

The capability-based entrepreneurial framework has been discussed and empirically analyzed in two major ways- one is institution based and another one is individual skill and knowledge-based. Notably, EC analyses have been conducted in the context of the cross-country or regional block setting. For instance, Šebjan et al. (2016) performed a cross-country analysis of entrepreneurship intention in the Danube region. To the best of our knowledge, a macro-level empirical analysis in the capability-based entrepreneurship framework is yet to perform. There are very few studies have been conducted applying econometric methods, particularly Stochastic Frontier Analysis (SFA) for dismantling EC based framework in the regional level. Therefore, this study takes this issue as the main gap of existing literature.

\section{Selection of countries}

The Association of South East Asian Nations (ASEAN) was formed in 1967 by Indonesia, Malaysia, Philippines, Singapore and Thailand to promote intergovernmental cooperation and to facilitate economic, educational, military, political and cultural integration amongst the member countries and Asian nations. Subsequently, the membership of the organization has been expanded by the inclusion of Brunei, Cambodia, Laos, Myanmar and Vietnam. The major aim of ASEAN is an acceleration of economic growth in the region. In 2015, the combined nominal GDP of the organization was more than US\$2,432 billion ${ }^{1}$. After the USA, China, Japan, France and Germany, ASEAN would be the sixth largest economy in the world if it were a country ${ }^{1}$. ASEAN-05 (The founder nations of ASEAN) possesses some common attributes. ASEAN-05 is endeavoring to uplift from efficiency to technology-driven economy (Afzal and Lawrey 2014). These attributes are identically accepted from economic to social aspects.

The ASEAN Free Trade Area (AFTA) has been in operation since 1992 for bringing down the intra-regional tariff charges. The governmental education expenditure of the ASEAN-5 is around 20\% of their total expenditure except for Philippines (ASEAN Secretariat 2014). The primal export of ASEAN-05 is a high-tech product other than Indonesia (Capannelli 2014). In recent times, the majority percentage of exports of these countries are ICs (Integrated Circuits) and computer data storage units (Simoes, Landry, Hidalgo and Teng 2016). This implies the strong technological advancement of ASEAN-05. The ASEAN Economic Community (AEC) is heading towards 
technology-driven production advantages. The AEC is trying to establish an economic region with a high level of competition, which requires a policy that includes competition policy based on advance innovation system by creating entrepreneurship capability environment development.

Based on the ASEAN Economic Blueprint, AEC becomes very necessary to reduce the gap among ASEAN countries in terms of economic growth and this can only be possible by encouraging more entrepreneurial activities in the region. Thus, to address a sustainable economic growth, AEC can promote the concept of entrepreneurship capability-based model using the factors which affect the EC framework in this region. Fig. 1 exhibits the transition of ASEAN-05 economies towards the innovation-driven economy.

\section{Data and variable selection}

This study considers one dependent variable and six independent variables. The dependent variable is the perceived capabilities of the entrepreneur (PerCa). The independent variables are Fear of Failure rate (Fefra), Entrepreneurship as Good Career Choice (EnGC), Perceived Opportunity (PO), Knowledge Transfer (KT), Intellectual Property Rights (IPR) and Educational Quality and standard of a university (UE). The study utilizes datasets of the Global Entrepreneurship Monitor (GEM) and the World Competitiveness Yearbook (WCY) -2016.

These variables are supported by other literatures also. PerCa is the required skills and knowledge to start a business. Venkataraman (1997) argues that an entrepreneur should possess the necessary skills and knowledge in the development of a new venture. According to Shane (2000), the entrepreneurial skill comprises with the technological embodied knowledge. Fear of failure (FefRa) variable has a powerful impact (generally negative) upon the entrepreneurial venture creation and it may refrain the entrepreneurs from exhibiting their potentials (Arenius and Minniti 2005; Politis and Gabrielsson 2009). This study considers the state of entrepreneurship as a good career choice (EnGC) which is supported by several studies as the important explanatory variable (Davidsson 1995; Krueger 1993; Autio, Keeley, Klofsten, Parker and Hay 2001).

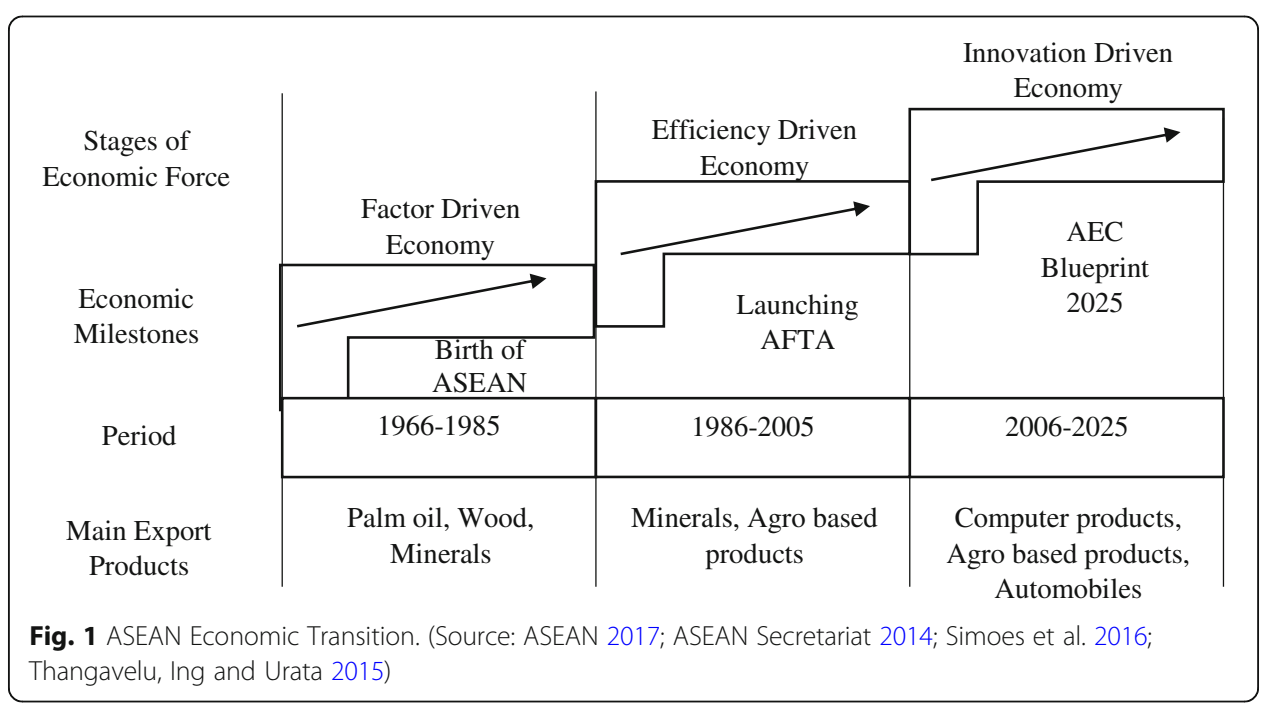


Another independent variable is perceived opportunity (PO). This variable plays up the social and cultural comprehensions and enables to foresee the productive chances of the firm (Druilhe and Garnsey 2004; Penrose 1959).

The transformation of knowledge paves the way for innovation and entrepreneurial activities developed by the innovation process (Afzal 2013; Etzkowitz, Webster, Gebhardt and Terra 2000). Therefore, knowledge transfer (KT) is considered as another independent variable in this study. Thomas and Carl (2001) argue property right protects the knowledge and helps to sustain the knowledge-based practice. Thus, this study entitles Intellectual Property Rights (IPR) as an independent variable. The educational quality and standard of a university directly influence the entrepreneurial activities in the country which is represented by (UE) variable in the current study. This activity also helps promoting a competitive economy by building young entrepreneurs in tertiary level (Lockett and Wright 2005; Siegel, Waldman, Atwater and Link 2003). The detail explanation of the variables is included in the Appendix Table 2.

\section{Empirical methodology}

The purposes of this study are to find the determinants of Entrepreneurial Capability which identifies and endeavor commercial opportunities in the Association of South East Asian Nations - 5 economies, namely Indonesia, Malaysia, the Philippines, Singapore and Thailand and empirically tests the efficiency and imperative coefficients of variables that have an impact on Entrepreneurial Perceived Capabilities. Non-parametric tests as oppose to parametric counterpart, can only test the efficiency ranking of decision making units, however, Log Linear Stochastic Production Frontier model can find out reason of inefficiency. Thus, this study uses parametric tests, e.g. log linear SFA model.

Stochastic Frontier Analysis (SFA) models were initially introduced by Aigner, Lovell and Schmidt (1977) and Meeusen and Broeck (1977). SFA models are one of the popular sub-disciplines of econometrics while analyzing efficiency, productivity, the cause of inefficiency and coefficients of interest in the parametric context as oppose to non-parametric models such as DEA, (see Kumbhakar and Lovell (2003) for an introduction of SFA models).

Pitt and Lee (1981) and Schmidt and Sickles (1984) were the first few researchers who use SFA with random effects and time-invariant inefficiency in fixed effects panel model context. However, these models are not used in this current study. Firstly, as Greene (2005) argued, handling of the effect of the models in Pitt and Lee (1981) and Schmidt and Sickles (1984) neglect the possibility of other non-efficiency related time-variant heterogeneity which could affect the estimations of efficiency yielding biased results. Secondly, the assumptions of time-invariant inefficiencies demonstrate inappropriate for long time series (Kumbhakar 1990; Battese and Coelli (1992).

Therefore, a possible linear- and quadratic time trend in efficiency will be included in the model which is used in this research. To analyze our data for fitting results, this study has applied an SFA model, proposed by Bates and Coelli (1992) and moderated by Chen et al. 2014. This model is commonly known as a log transformation frontier model using frontier command Xtfrontier. The transformation method removes the potential issues caused by the incidental parameter problem (Wong, Ho and Singh 2007). 
overall, a stochastic frontier model has two components. One component is assumed to have a strictly nonnegative distribution and whilst the other component has a symmetric distribution. In the econometrics, the nonnegative element is often stated to as the inefficiency term and the factor in the symmetric distribution is termed idiosyncratic error (Belotti and Ilardi 2015; Chen et al. 2014; Constantin and Iyer 2011).

Xtfrontier command allows two different parameterizations of the inefficiency term: a time-invariant model and parameterization of time effects (Battese and Coelli 1992). In the time-invariant model, the inefficiency term is presumed to have a truncated-normal distribution. In the Battese and Coelli (1992) parameterization of time effects, the inefficiency term is modeled as a truncated-normal random variable elevated by a specific function of time. In both models, the idiosyncratic error term has a normal distribution. The lone panel-specific effect is the random inefficiency term in this case.

In order to capture the factors that affect the entrepreneurial capabilities, we formulate the log-linear time decaying model based on simple SFA panel model idea to identify the inefficiency variation over the years in our sample countries (Keller 2002: Technology Diffusion and the World Distribution of Income: The Role of Geography, Language, and Trade, unpublished; Pesaran et al., 2013). The systematic summarization of methodology is as follows: (Fig. 2).

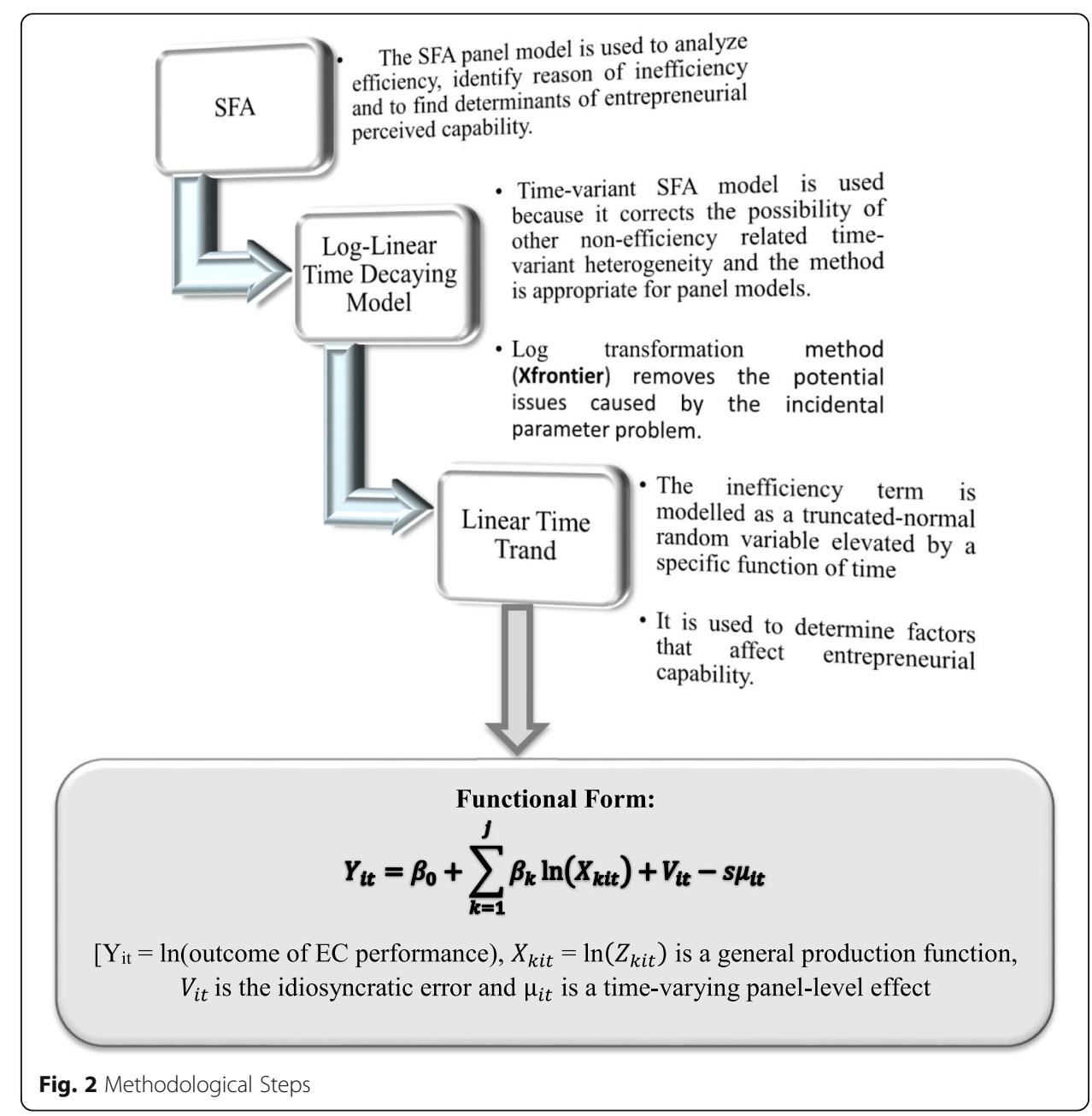




\section{Result and discussion}

Table 1 consists of internal and external factors that affect the entrepreneurial perceived capabilities environment in ASEAN-05 economies. The dependent variable Entrepreneurial Perceived Capabilities (PerCa) are explained by a set of independent variables in the model. According to GEM database, (PerCa) refers percentage of 1864 population who believe that they have the required skills and knowledge to start a business. This may be in academia or in the general population.

The independent variables result suggests that all most all the coefficients of the variables are positive except in the case of the Fear of Failure Rate variable (FefRa). This reveals that the influence of role models and prior entrepreneurial experience and the perception of social support factors and government policy, such as Intellectual Property Rights (IPR) are not significantly supported by EC in ASEAN-05 economies. By looking at IPR variable in the model, we can draw the above statement more clearly. The IPR variable in the model is positive yet insignificant. The fear of failure variable comes with a negative sign in the model which implies EC performance and fear of failure have an inverse relationship. The more fear of failure in the mind of the entrepreneur, the less application of their skill and knowledge for seeking new ventures in the economy. This is an important finding for the policymakers of ASEAN-05 to rethink the EC supporting environment.

The impact of the Entrepreneurial Opportunities (PO) on output is positive and significant in the model from Table 1. The results also exhibit that the EC environment affecting factors such as Entrepreneurship as a Good Career Choice (EnGC) has a positive and significant impact on the determination of the production frontier. Knowledge Transfer Rate (KT) and University Education System (UE) are positive and significant in the model from Table 1.

This implies that universities in ASEAN-05 are concentrating on promoting EC capability-based outcomes, such as technology transfer, new patent, commercialization of scientific invention and licensing facilities. This is very vital for entrepreneurial capability development as these are the key external factors that affect immensely the outcome of EC activity and improve efficiency frontier for the nations.

If we compare our findings with recent EC pieces of literature on ASEAN-05, we can find evidence to support our empirical results. A study on the relationship between individual researcher's work environment and their engagement with entrepreneurship activity in Thailand shows that commercialization of academic entrepreneurs' research outputs plays an important role for social changes (Sooampon and Igel 2014). In that

Table 1 Log transformation frontier model results

\begin{tabular}{lllllll}
\hline Dependent variable PerCa_log & Coef. & Std. Err. & $\mathrm{z}$ & $\mathrm{P}>|z|$ & \multicolumn{2}{l}{ [95\% Conf. Interval] } \\
\hline FefRa_log & .271308 & .0760363 & 3.57 & 0.000 & .1222805 & .4203373 \\
PO_log & .4017503 & .122001 & -3.29 & 0.001 & -.6408679 & -.1626328 \\
EnGC_log & .9734191 & .1095154 & 8.89 & 0.000 & .7587729 & 1.188065 \\
KT_log & .1073086 & .0840422 & 1.28 & 0.002 & .2720284 & .0574111 \\
IPR_log & .0101934 & .0991004 & 0.10 & 0.918 & -.1840397 & .2044265 \\
UE_log & .3676244 & .1079669 & 3.10 & 0.001 & .5792356 & .1560131 \\
_cons & 3.325477 & 8.465878 & 0.39 & 0.694 & -13.26734 & 19.91829 \\
\hline
\end{tabular}

Source: Author calculation 
study, the entrepreneurial capability is defined as an experience in transforming scientific expertise into a commercial product or service to be sold in the market. However, university-industry-government linkages are not favorable in Thailand, but public universities encouraged entrepreneurial activities (Intarakumnerd and Schiller 2009).

In Singapore, the economy is basically dependent on industry and service entrepreneurship. Singapore universities and government policy have a major contribution to knowledge generation in commercialization through entrepreneurship (Sohn and Kenney 2007). The National University of Singapore is being entrepreneurial and is playing the role of economic development (Wong, Ho and Singh 2007). Only after 3 years of initializing the Entrepreneurial University project, Malaysia's knowledge output in the total number of publications and patents has increased. Not only publications but citation numbers also have increased (Wong and Goh 2010; Razak and Saad 2007). Indonesia and the Philippines are catching up the frontier slowly but surely. The only problem prevails at the moment is the proper government policy in place to maintain IPR law and regulatory policy to let entrepreneurs to take risks and do not fear to take entrepreneurship as a good career choice frequently in ASEAN-05. Therefore, the results of this current study on ASEAN-05 will certainly help policymakers to set a proper environment of $\mathrm{AE}$ capabilities in the individual countries and the region as a whole. Therefore, the main difference of this study with previous studies is that other studies support that the countries are improving knowledge transfer and economic growth through entrepreneurial activities, whereas the present study has found the factors that accelerate entrepreneurial capabilities. The similarity of the present study and previous studies is that these studies have found commercialization of research product, knowledge transfer as positive and fear of failure rate as a negative catalyst in entrepreneurial capabilities. From the overall results of Table 1, all these seem to suggest that the efficiency estimates derived from the application of the log transformation stochastic frontier model are relatively robust to the distributional assumptions that we made.

\section{The reason of cross-country efficiency difference}

If we compare our findings with recent EC pieces of literature, this study finds theoretical evidence to support our empirical results, especially the importance of university education standard and knowledge transfer between university-industry to build up skilled entrepreneurs in the country. For example, according to Aghion, Howitt and Mayer-Foulkes (2005) theory, let's assume that there are two countries namely Malaysia and Indonesia in which both the countries have identical resource endowment, except that skilled entrepreneur is scarcer in Indonesia than in Malaysia, identify as

$$
H^{I} / L^{I}<H^{M} / L^{M}
$$

Where $\mathrm{L}$ and $\mathrm{H}$ stand for the amounts of unskilled and skilled entrepreneur employed in technology enhancing sector. 'I' and 'M' represent the short form of Indonesia and Malaysia respectively. Now, we assume that IPR law is not enforced in the ' $\mathrm{I}$ ' and that there is no trade between ' $\mathrm{I}$ ' and ' $\mathrm{M}$ '. This also implies that intermediate producers in the ' $\mathrm{M}$ ' cannot sell any goods which needs copyright protection to 'I'. Thus, 'M' can only collect copyright rents from domestic innovators. On the other 
hand, the entrepreneurs in ' $\mathrm{I}$ ' can imitate new technologies invented in ' $\mathrm{M}$ ' at a small cost. This also discourage entrepreneurs of 'I' to innovate on their own. At one point, both the countries will end up using the same technologies and thus productivity at one-point reach at steady state in that region (here we assume, in two country case). There will be no incentive to invent for innovators or entrepreneur in both the countries.

Therefore, numerically speaking,

$$
\frac{A_{H}}{A_{L}}=\frac{H}{L}
$$

Where A is the productivity parameter. Therefore, government policy like IPR law is a crucial incentive for a region to innovate and remain competitive. The absence of such variables not only create the disincentive to the entrepreneurs but also are the reason for the cross-country efficiency difference. Therefore, university education standard, knowledge transfer rate and IPR law are significant external factors to enhance entrepreneurial capabilities in a single country or a region as a whole.

\section{Conclusion and contribution}

This study presents an SFA model to estimate the entrepreneurial perceived capabilities affecting environmental factors in ASEAN-05. The estimation of the variables that influences the efficiency of EC among the countries is beneficial to improve the entrepreneurial eco-system. This provides feedback to the policy makers and points out the deficiencies in enhancing EC performances through skill and knowledge development process.

By the results of the analysis, this research exhibits that the production or factor affecting entrepreneurial perceived capabilities' inputs such as, perceived opportunities in the country, entrepreneurship as a good career choice, fear of failure, intellectual property rights, knowledge transfer rate and overall university education system have significant impact on the determination of the production frontier. Moreover, perceived opportunities in the country for the entrepreneur, entrepreneurship as a good career choice is the most affecting variables to measure the quality of the EC environment as opposed to fear of failure rate in the entrepreneurs' mindset.

The external variables such as the knowledge transfer rate between university-industry and overall university education system in the country are positive in ASEAN-05. It would seem that these two factors are the most important variables to consider for the future perfection of production frontier. The methodology described in this work is appropriate for the evaluation of the efficiency and coefficient determination of EC environment.

Given the overall discussion and strategic priority variables of ASEAN-05 region, several policy implications can be pursued. Practically speaking, policy issues which may affect the key determinants in the individual entrepreneurial decision -making process must consider enhancing knowledge transfer rate opportunities, improve standards of university education system while at the same time lowering fear of failure from their mindset. We have not found any similar study based on other regional block, e.g. BRICS, SAARC. We have worked with ASEAN block using macro data from GEM. Therefore, in order to draw practical implication, we can say that this study can be replicated in case of other regional blocks. Moreover, we have found several studies based on entrepreneurial intention but not on entrepreneurial perceived capability. Thus, finding the determinants of entrepreneurial 
capability are important to accelerate a country as well as region towards innovation driven development. Further, the studies discuss how entrepreneur works in professional and academic world in general, which has never been addressed in the ASEAN before.

Past studies have illustrated the differences in entrepreneurial intentions from cross-cultural and cross-country perspective (for example Liñán and Chen 2009; Šebjan et al. 2016) in Taiwan, Danube region, Spain but our study contributes to reinstate the definition of entrepreneurial capabilities and demonstrate how this capability affecting factors shape the overall entrepreneurship process in ASEAN-05 from a stable panel stochastic frontier analysis. This was missing in many entrepreneurship studies like Ramli and Senin (2015), Ismail, Nor and Sidek (2015), binti Hamidon, bin Suhaimie, bin Mat Yunoh and binti Hashim (2017), and Binti Othman and Othman (2017).

\section{Limitations and future research}

Future researchers can take a micro level individual university specific survey on young entrepreneurs and look for socio-cultural factors that shape the EC environment in ASEAN-05. Lack of sufficient time series data and application of non-parametric methods for comparison are the fundamental limitations of this study. However, even with our limited data, the method and the results achieved already provide a useful interpretation of the efficiency frontier for the evaluation of EC performance study. Finally, we can say that entrepreneurship is not only the result of individual's skill, knowledge and seeking new venture but also, to the same extent, a result of the environment of a university system, knowledge transfer rate, government policy such IPR law in which an entrepreneur lives and works.

\section{Endnotes}

${ }^{1}$ Source: ASEAN Secretariat and IMF World Economic Outlook April, 2016.

\section{Appendix}

Table 2 Description of variables

\begin{tabular}{|c|c|c|c|}
\hline Variable & $\begin{array}{l}\text { Short } \\
\text { Form }\end{array}$ & Explanation & Source \\
\hline $\begin{array}{l}\text { Perceived capabilities of } \\
\text { the entrepreneur }\end{array}$ & PerCa & $\begin{array}{l}\text { Percentage of 18-64 population who believe they have the } \\
\text { required skills and knowledge to start a business }\end{array}$ & GEM \\
\hline Fear of failure & Fefra & $\begin{array}{l}\text { Percentage of } 18-64 \text { population perceiving good opportunities } \\
\text { to start a business who indicate that fear of failure would } \\
\text { prevent them from setting up a business }\end{array}$ & GEM \\
\hline Good career choice & EnGC & $\begin{array}{l}\text { Percentage of } 18-64 \text { population who agree with the statement } \\
\text { that in their country, most people consider starting a business } \\
\text { as a desirable career choice }\end{array}$ & GEM \\
\hline Perceived opportunity & $\mathrm{PO}$ & Sufficient venture opportunities are there in the country & GEM \\
\hline Knowledge transfer & KT & $\begin{array}{l}\text { Knowledge transfer is highly developed between companies } \\
\text { and universities (Updated: MAY 2016, IMD WCY executive } \\
\text { survey based on an index from } 0 \text { to 10) }\end{array}$ & WCY \\
\hline Intellectual Property Rights & IPR & $\begin{array}{l}\text { Intellectual property rights are adequately enforced (Updated: } \\
\text { MAY 2016, IMD WCY executive survey based on an index from } \\
0 \text { to 10) }\end{array}$ & WCY \\
\hline $\begin{array}{l}\text { Educational quality and } \\
\text { standard of a university }\end{array}$ & UE & $\begin{array}{l}\text { University education meets the needs of a competitive } \\
\text { economy (Updated: MAY 2016, IMD WCY executive survey } \\
\text { based on an index from } 0 \text { to 10) }\end{array}$ & WCY \\
\hline
\end{tabular}


Availability of data and materials

Already added as Additional file to this submission.

\section{Authors' contributions}

Introduction, Theoretical Background, Framework, Functional derivation, Methodology, Results and Discussion sections are done by corresponding author. Conclusion and Contribution, References formatting, editing sections and revisions of referee comments are done by Co-authors. All authors read and approved the final manuscript.

\section{Competing interests}

The authors declare that they have no competing interests.

\section{Publisher's Note}

Springer Nature remains neutral with regard to jurisdictional claims in published maps and institutional affiliations.

\section{Author details}

${ }^{1}$ Faculty of Business, Economics \& Accountancy, University Malaysia Sabah (UMS), Kota Kinabalu, Malaysia. ${ }^{2}$ Department of Economics, Shahjalal University of Science \& Technology (SUST), Sylhet, Bangladesh. ${ }^{3}$ School of Commerce, University of Southern Queensland, Toowoomba, Australia. ${ }^{4}$ School of Business and Quality Management, HBMSU, Dubai, UAE. ${ }^{5}$ Shahjalal University of Science and Technology (SUST), Sylhet, Bangladesh.

Received: 31 January 2018 Accepted: 22 May 2018

Published online: 29 May 2018

References

Afzal, MNI. (2013). Are science valleys and clusters panacea for a knowledge economy? An investigation on regional innovation system (RIS): Concepts, theory and empirical analysis. Asian Research Policy (ARP), 4(2), 114-125.

Afzal, MNI, \& Lawrey, R. (2014). Measuring the importance and efficiency of research and development expenditures in the transformation of knowledge-based economies: A case study of the ASEAN region. International Journal of Asia-Pacific Studies, 10(1), 33-47.

Afzal, M. N. I., Mansur, K. B. H. M., \& Sulong, R. S. (2017). An empirical investigation of triple Helix and National Innovation System Dynamics in ASEAN-5 economies. Asian Journal of Innovation and Policy, 6(3), 313-331. DOl: http//dx.doi.org/https://doi.org/10.7545/ajip.2017.6.3.313.

Aghion, P, Howitt, P, Mayer-Foulkes, D. (2005). The effect of financial development on convergence: Theory and evidence. Quarterly Journal of Economics, 120, 173-222.

Ahmed, I, Ali, G, Ramzan, M. (2014). Leader and organization: The impetus for individuals' entrepreneurial orientation and project success. Journal of Global Entrepreneurship Research, 4, 1.

Aigner, D, Lovell, CK, Schmidt, P. (1977). Formulation and estimation of stochastic frontier production function models. Journal of Econometrics, 6(1), 21-37.

Antonioli, D, Nicolli, F, Ramaciotti, L, Rizzo, U. (2016). The effect of intrinsic and extrinsic motivations on academics' entrepreneurial intention. Administrative Sciences, 6(4), 15-25.

Arafat, MY, \& Saleem, I. (2017). Examining start-up intention of Indians through cognitive approach: A study using GEM data. Journal of Global Entrepreneurship Research, 7(13).

Arenius, P, \& Minniti, M. (2005). Perceptual variables and nascent entrepreneurship. Small Business Economics, 24(3), 233-247.

ASEAN (2017). ASEAN Declaration on Innovation. [online] Available at: http://asean.org/storage/2017/11/01-ASEANDECLARATION-ON-INNOVATION-as-of-Oct16-Final-for-Adoption-clean....pdf [Accessed 30 Dec. 2017].

ASEAN Secretariat (2014). ASEAN State of Education Report 2013. Jakarta, Indonesia: ASEAN Secretariat.

Audu, SI, Otitolaiye, JO, Ibitoye, SJ. (2013). A stochastic frontier approach to measurement of cost efficiency in small scale cassava production in Kogi state, Nigeria. European Scientific Journal, 9(9).

Autio, EH, Keeley, R, Klofsten, M, GC Parker, G, Hay, M. (2001). Entrepreneurial intent among students in Scandinavia and in the USA. Enterprise and Innovation Management Studies, 2(2), 145-160.

Battese, GE, \& Coelli, TJ. (1992). Frontier production functions, technical efficiency and panel data: With application to paddy farmers in India. Journal of Productivity Analysis, 3(1), 153-169.

Belotti, F, \& llardi, G (2015). Consistent inference in fixed-effects stochastic frontier models. In Working paper (November $7 R \& R$ version).

Bergmann, H, Mueller, S, Schrettle, T. (2014). The use of global entrepreneurship monitor data in academic research: A critical inventory and future potentials. International Journal of Entrepreneurial Venturing, 6(3), 242-276.

Binti Hamidon, IN, Bin Suhaimie, MH, Bin Mat Yunoh, MN, Binti Hashim, H. (2017). Entrepreneurial intention among employees: An insight of entrepreneurial university in Malaysia. International Journal, 2(3), 01-13.

Binti Othman, N, \& Othman, SH. (2017). The perceptions of public university students of entrepreneurship education in Malaysia. International Business Management, 11(4), 865-873.

Cantu-Ortiz, FJ, Galeano, N, Mora-Castro, P, Fangmeyer, J. (2017). Spreading academic entrepreneurship: Made in Mexico. Business Horizons, 60(4), 541-550.

Capannelli, G (2014). The ASEAN Economy in the Regional Context: Opportunities, Challenges, and Policy Options (No. 145). In ADB Working Paper Series on Regional Economic Integration.

Chen, YY, Schmidt, P, Wang, HJ. (2014). Consistent estimation of the fixed effects stochastic frontier model. Journal of Econometrics, 181(2), 65-76.

Clarysse, B, Tartari, V, Salter, A. (2011). The impact of entrepreneurial capacity, experience and organizational support on academic entrepreneurship. Research Policy, 40(8), 1084-1093.

Constantin, P, \& Iyer, G. (2011). A stochastic-Lagrangian approach to the Navier-stokes equations in domains with boundary. The Annals of Applied Probability, 21(4), 1466-1492. 
Davidsson, P (1995). Determinants of entrepreneurial intentions. In RENT IX workshop in entrepreneurship research, Piacenza, Italy (23-24 November).

D'este, P, Mahdi, S, Neely, A (2009). Academic entrepreneurship: What are the factors shaping the capacity of academic researchers to identify and exploit entrepreneurial opportunities? In Summer Conference on CBS. Frederiksberg: Copenhagen Business School.

Druilhe, C, \& Garnsey, E. (2004). Do academic spin-outs differ and does it matter? The Journal of Technology Transfer, 29(3), 269-285.

Etzkowitz, H. (2014). The entrepreneurial university wave: From ivory tower to global economic engine. Industry \& Higher Education, 28(4), 223-232.

Etzkowitz, H, Webster, A, Gebhardt, C, Terra, BRC. (2000). The future of the university and the university of the future: Evolution of ivory tower to entrepreneurial paradigm. Research Policy, 29(2), 313-330.

Giuri, P, Grimaldi, R, Villani, E. (2014). Supporting academic entrepreneurship: Cross-country evidence in Europe. Journal of Industrial and Business Economics, 41(4), 180-200.

Greene, W. (2005). Reconsidering heterogeneity in panel data estimators of the stochastic frontier model. Journal of Econometrics, 126(2), 269-303.

Hallam, C, Novick, D, Gilbert, DJ, Frankwick, GL, Zanella, G. (2017). Academic entrepreneurship and the entrepreneurial ecosystem: The UT transform project. Academy of Entrepreneurship Journal, 23(1), 77-90.

Intarakumnerd, P, \& Schiller, D. (2009). University-industry linkages in Thailand: Successes, failures, and lessons learned for other developing countries. Seoul Journal of Economics, 22(4), 551-560.

Ismail, N, Nor, MJM, Sidek, S. (2015). A framework for a successful research products commercialisation: A case of Malaysian academic researchers. Procedia-Social and Behavioral Sciences, 195, 283-292.

Klofsten, M, \& Jones-Evans, D. (2000). Comparing academic entrepreneurship in Europe-the case of Sweden and Ireland. Small Business Economics, 14(4), 299-309.

Krueger, N. (1993). The impact of prior entrepreneurial exposure on perceptions of new venture feasibility and desirability. Entrepreneurship: Theory and Practice, 18(1), 5-22.

Kumbhakar, SC. (1990). Production frontiers, panel data, and time-varying technical inefficiency. Journal of Econometrics, 46(1-2), 201-211.

Kumbhakar, SC, \& Lovell, CK (2003). Stochastic frontier analysis. Cambridge: Cambridge University Press.

Light, I, \& Dana, LP. (2013). Boundaries of social capital in entrepreneurship. Entrepreneurship Theory and Practice, 37(3), 603-624.

Liñán, F, \& Chen, YW. (2009). Development and cross-cultural application of a specific instrument to measure entrepreneurial intentions. Entrepreneurship Theory and Practice, 33(3), 593-617.

Lockett, A, \& Wright, M. (2005). Resources, capabilities, risk capital and the creation of university spin-out companies. Research Policy, 34(7), 1043-1057.

Meeusen, W, \& van Den Broeck, J. (1977). Efficiency estimation from cobb-Douglas production functions with composed error. International Economic Review, 435-444.

Miranda, FJ, Chamorro-Mera, A, Rubio, S. (2017). Academic entrepreneurship in Spanish universities: An analysis of the determinants of entrepreneurial intention. European Research on Management and Business Economics, 23(2), 113-122.

Nazaryeva, K. (2015). Academic Entrepreneurship in the Context of a Technology Transfer The Office A Case from Brazil. Master's thesis, University of Oslo.

Nyström, K. (2008). The institutions of economic freedom and entrepreneurship: Evidence from panel data. Public Choice, 136(3), 269-282.

Penrose, ET (1959). The theory of the growth of the firm. New York: Wiley.

Pesaran, MH, Smith, LV, Yamagata, T. (2013). Panel unit root tests in the presence of a multifactor error structure. Journal of Econometrics, 175(2), 94-115.

Pitt, MM, \& Lee, LF. (1981). The measurement and sources of technical inefficiency in the Indonesian weaving industry. Journal of Development Economics, 9(1), 43-64.

Politis, D, \& Gabrielsson, J. (2009). Entrepreneurs' attitudes towards failure: An experiential learning approach. International Journal of Entrepreneurial Behavior \& Research, 15(4), 364-383.

Ramli, MF, \& Senin, AA. (2015). Success factors to reduce orientation and resources-related barriers in university-industry R\&D collaboration particularly during development research stages. Procedia-Social and Behavioral Sciences, 172, 375-382.

Rashed, F, Deluyi, AHM, Daud, K. (2015). Developing a mathematical model of entrepreneurship based on transformational leadership behavior. Jurnal Teknologi, 72(5), 125-131.

Razak, AA, \& Saad, M. (2007). The role of universities in the evolution of the triple helix culture of innovation network: The case of Malaysia. International Journal of Technology Management \& Sustainable Development, 6(3), 211-225.

Schmidt, P, \& Sickles, RC. (1984). Production frontiers and panel data. Journal of Business \& Economic Statistics, 2(4), 367-374.

Schumpeter, JR (1942). Capitalism, socialism and democracy. New York: Harper \& Row.

Scippacercola, S, \& D'Ambra, L. (2014). Estimating the relative efficiency of secondary schools by stochastic frontier analysis. Procedia Economics and Finance, 17, 79-88.

Šebjan, U, Tominc, P, Boršič, D. (2016). Cross-country entrepreneurial intentions study: The Danube region perspective. Croatian Economic Survey, 18(2), 39-76.

Shane, S. (2000). Prior knowledge and the discovery of entrepreneurial opportunities. Organization Science, 11(4), 448-469.

Siegel, DS, Waldman, DA, Atwater, LE, Link, AN. (2003). Commercial knowledge transfers from universities to firms: Improving the effectiveness of university-industry collaboration. The Journal of High Technology Management Research, 14(1), 111-133.

Siegel, DS, \& Wright, M. (2015). Academic entrepreneurship: Time for a rethink? British Journal of Management, 26(4), 582-595.

Simoes, A., Landry, D., Hidalgo, C., \& Teng, M. (2016). OEC: The observatory of economic complexity. Retrived from https://atlas.media.mit.edu/en/. Accessed 5 Apr 2018

Sohn, DW, \& Kenney, M. (2007). Universities, clusters, and innovation systems: The case of Seoul, Korea. World Development, 35(6), 991-1004.

Sooampon, S, \& Igel, B. (2014). The individual's perceived environment as an antecedent of academic entrepreneurship: Multiple case studies of Thai university researchers. Journal of Enterprising Culture, 22(01), 57-90. 
Thangavelu, SM, Ing, LY, Urata, S (2015). Services productivity and trade openness: Case of ASEAN. In ERIA Discussion Paper, (p. 56).

Thomas, A, \& Carl, D (2001). Korea and the knowledge-based economy making the transition: Making the transition. In OECD publishing.

Tiwari, P, Bhat, AK, Tikoria, J. (2017). A empirical analysis of the factors affecting social entrepreneurial intentions. Journal of Global Entrepreneurship Research, 7(9).

Tofighi, S, Teymourzadeh, E, Ghanizadeh, G. (2017). Academic entrepreneurship in a medical university: A system dynamics approach. International Review, 1(2), 58-72.

Venkataraman, S. (1997). The distinctive domain of entrepreneurship research. Advances in Entrepreneurship, Firm Emergence and Growth, 3(1), 119-138.

Wong, CY, \& Goh, KL. (2010). Modelling the behaviour of science and technology: Self-propagating growth in the diffusion process. Scientometrics, 84(3), 669-686.

Wong, PK, Ho, YP, Singh, A. (2007). Towards an "entrepreneurial university" model to support knowledge-based economic development: The case of the National University of Singapore. World Development, 35(6), 941-958.

Woo, S, Jang, P, Kim, Y. (2015). Effects of intellectual property rights and patented knowledge in innovation and industry value added: A multinational empirical analysis of different industries. Technovation, 43, 49-63.

Wright, M (2007). Academic entrepreneurship in Europe. London: Edward Elgar Publishing.

Submit your manuscript to a SpringerOpen ${ }^{\circ}$ journal and benefit from:

- Convenient online submission

- Rigorous peer review

- Open access: articles freely available online

- High visibility within the field

- Retaining the copyright to your article

Submit your next manuscript at $\gg$ springeropen.com 